\title{
Application of PROMETHEE-GAIA Method in the Entry Mode Selection Process in International Market Expansion
}

\author{
Assamoi Valerie Christian, Yabin Zhang, Coulibalykigbajah Salifou \\ School of Economics and Trade, Hunan University, Changsha, China \\ Email: assamoivale@yahoo.fr,yabinzhang@hnu.edu.cn,coolsalif25@yahoo.fr
}

Received 9 February 2016; accepted 16 April 2016; published 19 April 2016

Copyright (C) 2016 by authors and Scientific Research Publishing Inc.

This work is licensed under the Creative Commons Attribution International License (CC BY). http://creativecommons.org/licenses/by/4.0/

(c) (†) Open Access

\begin{abstract}
Selecting an entry mode for a new organization or expansion is of vital importance to a decision maker, as many potential qualitative and quantitative criteria are to be considered. Entry mode decision is the most critical decision in international expansion; it can affect the performance of the company in the future. This paper solves an entry mode selection problem using PROMETHEE (Preference Ranking Organization Method for Enrichment Evaluation) and GAIA (Geometrical Analysis for Interactive Aid) method which is an effective multi-criteria decision-making (MCDM) tool and is used to deal with complex problems. In order to follow this technique, an investigation has been operated for comparing 5 entry modes such us exporting, franchising, licensing, joint venture and foreign direct investment (FDI) according to 15 criteria. The results, obtained by multi-criteria evaluation, clearly show that this method of entry mode selection for an Ivorian company named FILTISAC is successful and applicable. It is empirically determined that joint venture is the most suitable entry mode for company expansion amongst those selected.
\end{abstract}

\section{Keywords}

Entry Mode Selection, PROMETHEE-GAIA Method, Market Expansion

\section{Introduction}

Business is the biggest activity in the world today and has become more important for countries and companies. The number of companies operating internationally is increasing constantly. Companies expand their activities overseas around the world in order to take advantage of expanded markets and resources that exist across borders. However, the process by which a company moves from their home market to new markets successfully and 
starts up an economic activity remains a challenge to many of them.

According to Papadopoulos \& Denis [1], companies that want to expand into foreign markets are faced with the challenge of choosing the best structural arrangements and these obstacles are becoming crucial in the companies' daily work. One of these challenges is selecting foreign markets and their entry mode. Choosing a new market for a new organization is of vital importance to a decision maker. O’Farrell \& Wood [2] and Pan \& Tse [3] state that entering new foreign markets demands a lot of organization and planning because decisions makers need to know the markets demands, the markets regulations, who are the competitors, and so on in the target market. Selecting the appropriate foreign markets for expansion is highly significant as well as key element of success or failure for the company's future prospects.

Once a foreign market has been chosen, the decision makers have to decide how best their company can enter in this specific market, Deresky [4]. Entry mode decision is the most critical decision in international expansion; it can affect the performance of the company in the future, Ekeledo and Sivakumar [5]. It is an arrangement that permits the company to enter a market with its products, technology, human skills, management and other resources, Root [6].

There are many different modes of entering into foreign markets. Each mode has its advantages and disadvantages. Companies can expand into foreign markets through the following five entry modes: exporting, licensing, joint venture, franchising and direct investment. Several theories have developed different factors that influence entry modes decisions such as Chen and Mujtaba [7], Root [6], Koch [8], Brassigton and Pettitt [9] and Hollensen [10]. Therefore, decision makers need to evaluate them carefully and determine the most suitable entry mode to expand.

The objective of this study is to provide all the necessary information in order to analyze and recommend the best possible entry mode to the company's business expansion in selected market. This can be realized by addressing a number of problems, sequentially by attempting to answer the questions, as follows: What factors need to be considered by companies before entering a foreign market? What entry mode should the company use to enter in the selected foreign market? Which method is the best to a quantitative method of entry mode analysis? In this paper, the preference ranking organization method for enrichment evaluation (PROMETHEE II) is employed to solve the problem of entry mode given that it is useful as method for more effectiveness and efficiency to enable company success in market expansion. A case study of a company that manufactures jute bags for packaging agricultural products will be used. The author mentions that the market has been selected in the previous study.

This study has great implication in giving direction to decision makers of companies, professional and academic economists, as well as research students and interested parties in the field of international business. Particularly, those learning international business as a practical example of company's expansion showing how to select foreign entry mode for expansion. Results could provide new insights of inquiries.

The rest of this paper has been structured as follows: Section 2 discusses literature on factors that affect firm's choice of foreign market entry mode and a short description of different entry modes. Section 3 sets out PROMETHEE-GAIA procedure and while Section 4 provides results and discussion. Eventually, Section 5 concludes.

\section{Literature Review}

\subsection{International Market Entry Mode}

In this section an overview of previous studies related to the research question is presented. The section is going to analyze foreign market entry mode, and then factors that influence company foreign market entry mode. Finally we presented a conceptual framework to understand the development of our paper.

According to Hollensen [11], entry modes for market expansion is an essential question for companies in today's rapidly growing and internationalizing market. The decision of how to penetrate a foreign market can have an important effect on the results. Root [6], states that the entry mode is the arrangement that permit the company to enter a market with its products, technology, human skills, management and other resources. It is the method used by companies to begin business in a foreign country. In the process of selecting entry modes, several factors must be taken into account prior to making the final decision. Companies can penetrate foreign markets in many different modes such us exporting, licensing, franchising, direct investment and joint venture.

Exporting is sale of domestically-produced goods in another foreign market. The company doesn't need to 
invest in the foreign market because all products are made at the company home country, Brassington and Pettitt [9]. It is the simplest mode of market expansion. There are four participants involved in the rule of exporting namely: exporter, importer, transport provider and the government. Further, they state that exporting is divided into two groups: direct and indirect export. Direct export is when a company produces the product at home and then sells it to the foreign market without using an intermediary. Indirect export, on the other hand, is when the company produces the product at home and then sells via an intermediary to a foreign market.

Another mode of market expansion is licensing. At this point a company named licensor sells its intellectual property, technology, work methods, patents, copy rights, brand name to another company named the licensee; in return the licensee must pay the fee in order to obtain the agreement with the licensor, Hill [12]. Licensing is the common mode used in foreign market entry because it involves little cost. Due to the unstable situation (political and economic), licensing is recommended to companies which are in their first stage of market expansion, Brassington and Pettitt [9].

Franchising is a popular entry mode used by most companies for market expansion. Franchising is a business arrangement that permits an organization, called the franchisee, to drive a business under another name, called the franchisor, in return for fee. The franchisor provides trademarks, an operating system and well-known product reputation to his franchisee, Armstrong and Kotler [13]. Franchising is a similar to licensing and it is divided in three groups: Manufacturer-sponsored retailer franchise system, for example car industry, Manufacturersponsored wholesaler franchise system, for example beverage industry and service-firm-sponsored retailer franchise system, common in fast-food Brassington and Petit [9].

Buckley \& Casson [14], point out that a joint venture is a union between two or more business partners. Joint ventures represent an accord between two groups to work jointly on a certain project in which they share risk, control, and profitability. More often than not, joint ventures are a fifty percent venture. It is a mode that both partnerships hold relatively equal percentage of shares in the venture, Prescott and Swartz [15]. The number of joint ventures is growing as is the case with rapid modification in technology and telecommunications. They also mentioned that in some cases, only one of the partners is responsible for management of joint venture.

Foreign direct investment (FDI) is the direct ownership of services in the foreign country. It concerns capital, technology, and personnel. On the other hand, investment entry modes are about obtaining ownership in a company that is located in the foreign country, Root [6], such as through classified licensing and franchising as a contractual entry mode and joint venture as an investment entry mode.

Each mode has its own advantages and disadvantages and the manager or the decision maker should select proper mode by considering different factors, Bradley [16]. Table 1 below summarizes some entry modes to international markets with brief description of each, its advantages and disadvantages.

Table 1. Different entry modes to international markets.

\begin{tabular}{|c|c|c|c|}
\hline Mode & Condition to use & Advantages & Disadvantages \\
\hline Exporting & $\begin{array}{l}\text { High target market, product cost, high } \\
\text { political risk, low home-country currency }\end{array}$ & $\begin{array}{l}\text { Relatively low financial exposure, } \\
\text { permit gradual, market entry Acquire } \\
\text { knowledge about local market }\end{array}$ & $\begin{array}{c}\text { Vulnerability to tariffs logistical } \\
\text { complexities potential conflicts with } \\
\text { distributors }\end{array}$ \\
\hline Licensing & $\begin{array}{c}\text { Licensing licks ability to become a } \\
\text { competitor, low sales, potential in targeted } \\
\text { market }\end{array}$ & $\begin{array}{l}\text { Lower cost and risk licensee provides } \\
\text { knowledge of local market }\end{array}$ & $\begin{array}{l}\text { No tight control, risk for losing } \\
\text { know-how }\end{array}$ \\
\hline Franchising & Contractual agreement & $\begin{array}{c}\text { Low financial risk, low cost way to } \\
\text { assess market potential, maintain more } \\
\text { control than with licensing }\end{array}$ & $\begin{array}{l}\text { Limits market opportunity, } \\
\text { dependence on franchisee, potential } \\
\text { conflicts with franchisee }\end{array}$ \\
\hline FDI & High sales potential low political risk. & $\begin{array}{l}\text { Greater knowledge of local market, } \\
\text { Can better apply specialized skills }\end{array}$ & $\begin{array}{l}\text { Higher risk than other modes } \\
\text { requires more resources and } \\
\text { commitments may be difficult to } \\
\text { manage the local resources }\end{array}$ \\
\hline Joint ventures & $\begin{array}{l}\text { High sales potential local company can } \\
\text { provide recourses and skills }\end{array}$ & $\begin{array}{l}\text { Benefit from local partner Share cost } \\
\text { and risk, Political considerations }\end{array}$ & $\begin{array}{c}\text { Loss control of technology, no tight } \\
\text { control of partner, Conflicts and } \\
\text { battles }\end{array}$ \\
\hline
\end{tabular}




\subsection{Factors Influencing on Selecting Entry Mode to International Markets}

Several studies have sought to identify a set of factors that influence entry mode decisions, Root [6], Koch [8], Chen and Mujtaba [7], Brassington and Pettit [9]. Most of them categorize influential factors affecting entry mode decision into two groups: external and internal factors. Internal factors consist of elements relating to the inside environment of the company, while the external are dependent on the outside environment of the company. In our paper, we focused on the following theories: the theory of Root [6], the theory of Koch [8] and the theory of Chen and Mujtaba [7].

In external factors, Root [6] develops four influential factors affecting entry mode selection. The first being to target Country Market Factors: Root [6] states that, the size of target country market influences entry mode selection. He argues that small markets use entry modes with low breakeven sale volumes (indirect distributor exporting, licensing and contracts) while markets with high potential uses entry modes with high breakeven sales volume (branch/subsidiary, exporting). Competitive structure of the market is also an influential element that the manager must be careful in the target market. In the target market if non-dominant competitors are many (atomistic), the company chooses most of the time export as entry mode because there is low resources commitment. But if the competition is monopolistic or oligopolistic, entry modes are high resource commitment to compete against competitors.

Secondly, Target Country Production Factors: Root [6] argues that the quality, quantity and cost of resources in the target market and also the quality and cost of economic infrastructure such us transportation, communication have an impact of selection of market entry mode. In the target market, if the production cost is high, the company use export as entry mode. Otherwise, when the production cost is low, the company prefers home production.

Thirdly, Target Country Environment Factors: Root [6] mentioned that foreign country environmental factors including political, economic, cultural and social property can influence the selection of market entry mode. The most significant factor of them is Government policies and regulations. Company need also to consider geographical distance when selecting entry mode. If the distance between the home and foreign country is long, transportation costs are high. Therefore, the choice of export as entry mode becomes complicated. The economy of the target country should also be taken into consideration while selecting the most suitable entry mode. Exchange rate policy, balance of payments, restrictions on the transfer of capital, profits and salaries can affect the choice of market entry mode. Cultural distance is also a pertinent factor in market expansion. Companies select those markets that are similar to its home country.

Lastly, Home Country Factors: Market, production and environment factors influence entry mode choice. If the market of the company home country is big, it permits a company to grow to a large size in the home market before its expansion. The competitive structure and policy of the home government are factors that need to be investigated carefully before taking the final decision. Geographical distance is another influential factor. The greater the geographical distance, the greater the probability that the company will choose investment as market entry mode, Root [6].

In internal factors, Root [6] has developed two influential factors namely: product factors, this is when the company products are much differentiated over those offered by their competitors; there is a degree of pricing discretion. As a consequence these products can absorb high unit transportation cost and high import duties and still remain competitive in a foreign market. Otherwise, if products are weakly differentiated, they have to compete on a price basis.

Company resource-commitments factors: Root [6] point out that the resources of an enterprise including management, capital, technology, production skills, and marketing skills influences on choosing entry mode for market expansion. The company that has many resources has many options for choosing entry mode. Otherwise, companies with limited resources are constrained to use entry modes with small resource commitment.

The following theory has been developed by Koch [8]. He divided as well influential factors of entry mode in three groups: internal, external and mixed factors. This paper focuses only on internal and external factors. In external factors, Koch [8] mentioned that market growth rate can influences entry mode decision. When the growth rate is fast in the market, the company utilizes this occasion by choosing an entry mode to expand rapidly. Otherwise, when growth rate of demand take a long period, the company tends to use joint venture and wholly-owned subsidiary as entry modes.

The author also argues that some characteristics of the foreign market are easy to get but information about the company specific information or industry is difficult to find. Furthermore, he regards that certain elements 
such as image support requirements, global management, efficiency requirements, and popularity of individual MEMs in the overseas market, industry feasibility/viability of MEM and market barriers (tariff barriers, governmental regulations, distribution access, natural barriers, exit barriers and level of country development) can influence the selection of entry mode.

Concerning the internal factors, Koch [8] claims that, the company size and its resources need to be considered during the selection of entry mode. Smalls companies with limited resources have few market entry modes option. Limited resources cannot allow them to choose some entry mode. Management locus of control can also influences market entry mode. This refers to manager perceptions, intuition and management style. Another internal factor is experience in using MEMs. Experience in using MEMs should be considered before selecting market entry mode. The degree of knowledge that the company has in the earlier market entries can guide them for the following market entry mode.

Koch [8] points out that the level of international business risk that the company takes in its entry mode decision depends on: the company's financial situation, its strategic options, and the competitiveness of the environment. Furthermore, Koch states that there are some factors such us market share target, calculation methods applied and profit target can influence market entry mode choice.

Chen and Mujtaba [7] divided the entry mode factors into three groups: firm-specific factors, country-specific factors and market-specific factors. Firm-specific factors are linked to TCE model (Transaction cost model). This is composed of asset specificity, international experience and firm size. Asset specificity talks about products and technologies. Chen and Mujtaba [7] mentioned that technology is a factor to which managers should pay attention. It can make diffusion risks. International experience has also been recognized as a factor effecting entry mode choice. Based on TCE approach is accumulation of knowledge of the company home market to avoid risk in international market transactions. Firm size is another influential factor. Chen and Mujtaba [7] discuss that firm with large size has a greater potential compare to small firm to expend resources and absorb risks.

Country-specific Factors Include: country-specific economic, political, legal, institutional and cultural factors. These factors should be considered in the entry mode decision process.

Finally, Market-specific factors include: market potential, demand uncertainty and competitive intensity. Chen and Mujtaba [7] argue that market potential (size and growth) has a great impact on the entry mode. When market potential is significant, a company selects high control entry mode. Companies have also a tendency to employ a higher-control entry mode when the demand of uncertainty in a foreign market is high. Competitive intensity should also be taken into consideration while selecting the most appropriate entry mode. Firms use a high control entry mode when the competitive intensity is high.

\subsection{Conceptual Framework}

To enhance understanding on the steps applied in gathering information for this study, a conceptual framework is employed to illustrate this. In the process of selecting entry modes, several influential factors must be taken into consideration before making the final decision. However, many authors have divided these factors in two or three groups. In this study, a set of factors, those have been frequently mentioned in the literature review, that also fit most of cases were chosen. For the conceptual framework, we have decided to use some influential factors mentioned above by Chen and Mujtaba [7], Root [6] and Koch [8]. The model of our conceptual framework is compounded of external and internal factors. In external factors group we have chosen geographical distance, cultural distance, political risk, government policies and regulations, home country factors, quality, quantity and cost, competitive structure, environment factors of Root [6] and market barriers of Koch [8]. Internal factors are included production factors of Root, market potential, and demand uncertainty, international experience of Chen \& Mujtaba [7], finally management risk attitude and company size of Koch [8].

After the decision maker evaluates the factors that influence the target foreign market, he will select the most suitable entry mode. Several researches identify export, contractual and investment as the main foreign market entry modes, Sitek [17], Rymarczyk [18], Duliniec, [19]. The contractual entry modes contain a variety of arrangements such as licensing, franchising, management contracts, turnkey contracts. The investment entry mode comprises acquisitions, joint venture and start-up investment and export mode includes indirect and direct export, intra corporate transfers. In our case, the paper will emphasis on the most common use by companies as licensing, franchising, joint venture, exporting and foreign direct investment (FDI). A graphical presentation of the conceptual framework is shown below (Graph 1). 


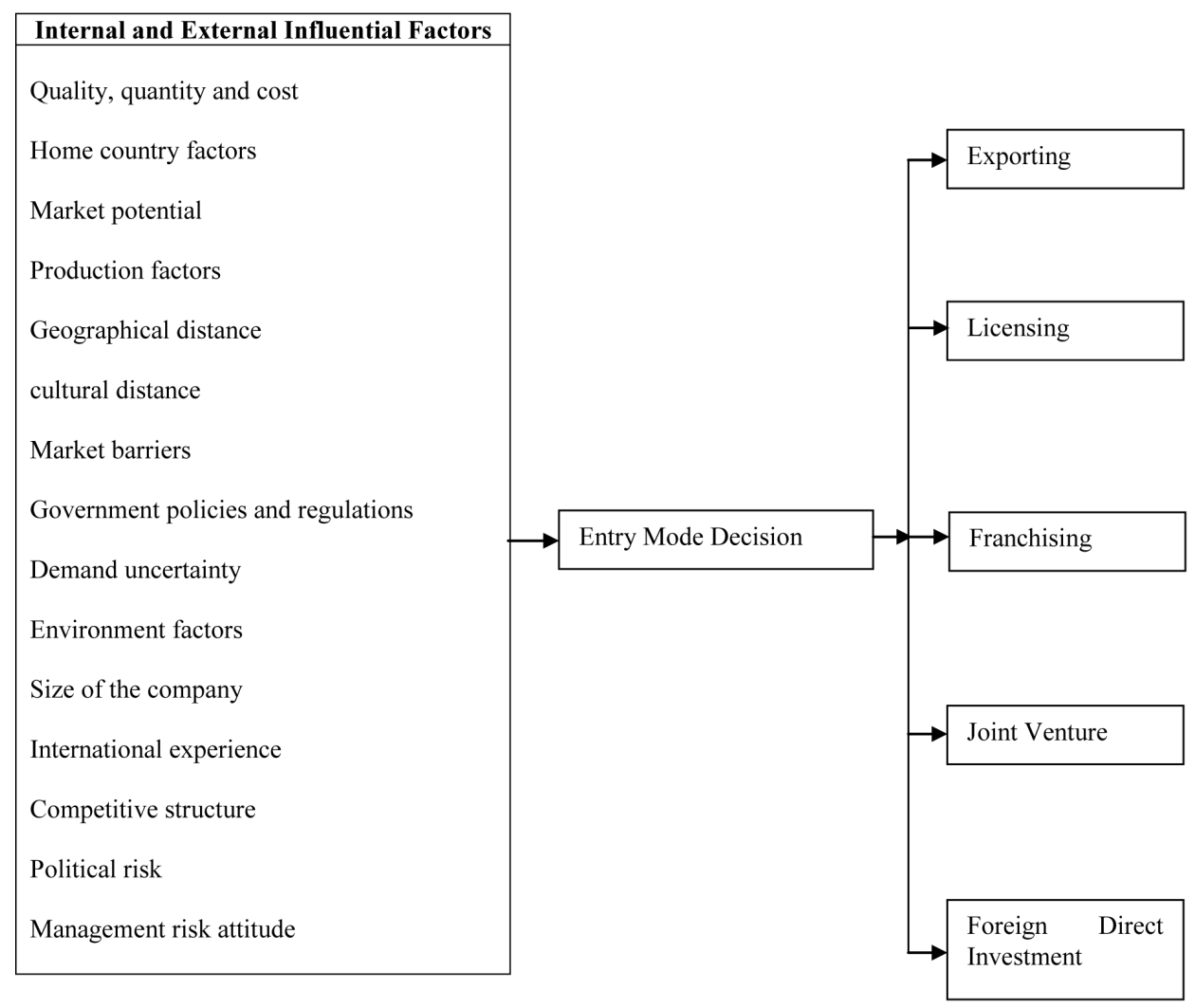

Graph 1. Presentation of the conceptual framework.

\section{Methodology}

The PROMETHEE (preference ranking organization method for enrichment evaluation) method was developed by Brans and Vincke [20]. It is a special type of MCDM tool that can provide a ranking ordering of the decision options and has been used in many business papers to solve many problems. The PROMETHEE I method can provide the partial ordering of the decision alternatives, whereas, PROMETHEE II method can derive the full ranking of the alternatives. In this paper, the PROMETHEE II method is employed to obtain the full ranking of the alternative in the entry modes selection process.

The procedural steps as involved in PROMETHEE II method are enlisted as below:

Step 1: Normalize the decision matrix using the following equation:

$$
R_{i j}=\left[X_{i j}-\min \left(X_{i j}\right)\right] /\left[\max \left(X_{i j}\right)-\min \left(X_{i j}\right)\right](i=1,2, \cdots, n: j=1,2, \cdots, m)
$$

where $X_{i j}$ is the performance measure of $i^{\text {th }}$ alternative with respect to $j^{\text {th }}$ criterion.

For non-beneficial criteria, Equation (1.1) can be rewritten as follows:

$$
R_{i j}=\left[\max \left(X_{i j}\right)-X_{i j}\right] /\left[\max \left(X_{i j}\right)-\min \left(X_{i j}\right)\right]
$$

The vector normalization denoted as $R_{i j}$ with $i=1, \cdots, m$ and $j=1, \cdots, n$ where $\mathrm{m}$ and $\mathrm{n}$ are respectively called alternatives and attributes. In fact $R_{i j}$ is the precondition to calculate $W_{i j}$ so it is fundamental. Following this multicriteria method, we intend to rank $n$ alternatives by using survey data.

Step 2: Calculate the evaluative differences of $i^{\text {th }}$ alternative with respect to others alternatives. This step involves the calculation of differences in criteria values between different alternatives pair-wise.

Step 3: Calculate the preference function, $P_{j}\left(i, i^{\prime}\right)$.

There are mainly six types of generalized preference functions as proposed by Brans and Mareschal these preference functions require the definition of some preferential parameters, such as the preference and indifference thresholds. However, in real time applications, it may be difficult for the decision maker to specify which 
specific form of preference function is suitable for each criterion and also to determine the parameters involved. To avoid this problem, the following simplified preference function is adopted here:

$$
\begin{gathered}
P_{j}\left(i, i^{\prime}\right)=0 \text { if } R_{i j} \leq R_{i^{\prime} j} \\
P_{j}\left(i, i^{\prime}\right)=\left(R_{i j}-R_{i^{\prime} j}\right) \text { if } R_{i j}>R_{i^{\prime} j}
\end{gathered}
$$

Step 4: Calculate the aggregated preference function taking into account the criteria weights.

Aggregated preference function,

$$
\pi\left(i, i^{\prime}\right)=\left[\sum_{j=1}^{m} w_{j} \times P_{j}\left(i, i^{\prime}\right)\right] / \sum_{j=1}^{m} w_{j}
$$

where $w_{j}$ is the relative importance (weight) of $j^{\text {th }}$ criterion.

$W_{j}$ is called the normalized weight of $\mathrm{j}$ criteria and it measures the importance of each criteria.

$W_{j}=W_{j} / \Sigma W_{j \cdot j}$ is defined as $\{1,2,3,4,5,6, \cdots, j\}$.

Step 5: Determine the leaving and entering outranking flows as follows:

Leaving (or positive) flow for $i^{\text {th }}$ alternative,

$$
\varphi^{+}(i)=\frac{1}{n-1} \sum_{i^{\prime}=1}^{n} \pi\left(i, i^{\prime}\right),\left(i \neq i^{\prime}\right)
$$

Entering (or negative) flow for $i^{\text {th }}$ alternative,

$$
\varphi^{-}(i)=\frac{1}{n-1} \sum_{i^{\prime}=1}^{n} \pi\left(i^{\prime}, i\right),\left(i \neq i^{\prime}\right)
$$

where $n$ is the number of alternatives.

Here, each alternative faces (n-1) number of other alternatives. The leaving flow expresses how much an alternative dominates the other alternatives, while the entering flow denotes how much an alternative is dominated by the other alternatives. Based on these outranking flows, the PROMETHEE I method can provide a partial preorder of the alternatives, whereas, the PROMETHEE II method can give the complete preorder by using a net flow, though it loses much information of preference relations.

Step 6: Calculate the net outranking flow for each alternative

$$
\varphi(i)=\varphi^{+}(i)-\varphi^{-}(i)
$$

Step 7: Determine the ranking of all the considered alternatives depending on the values of $\varphi(i)$. The higher value of $\varphi(i)$, the better is the alternative. Thus, the best alternative is the one having the highest $\varphi(i)$ value.

We apply the above method (PROMETHEE) to recommend the best entry mode used to expand internationally by a dynamically company that manufactures and distributes jute bags for packaging agricultural products. This company, FILTISAC S. A. (Filature, Tissage, and Sac-French name) is an enterprise establishes in Abidjan, Ivory Coast, West Africa in 1965 under the network of IPS WA (Industrial Promotion Services, West Africa), and an Institution of the Aga Khan Fund for Economic Development (AKFED). It occupies an area of land of approximately 102 acres, comprising of the factory, raw material and finished goods warehouses, the offices, the socio-medical structures, the sport facilities and residential accommodation. The company is present in four countries in West Africa (Cofisac and Fumoa) Senegal, (Embalmali) Mali, (Fasoplast) Burkina Faso and Niger. It has an annual turnover of about US \$ 300 million and operates in six major fields of activities such as packaging for transportation, packaging, metals, agro-Industry, infrastructures, and Small and Medium Businesses. The company has been expanded internationally because the domestic market is become too small to be profitable. To meet the local demand of packaging for coffee and cocoa beans and other agricultural products, the industrial modernization strategy began in 1986. Over the years substantial innovative investments have been made and continue to take place. Today the Jute Mill has a capacity of thirty million bags per year. Parallel to these activities, research, maintenance and quality control methods are given top priority to produce high quality products at international efficiencies and productivity ratios. Strict quality control and budgeting is undertaken at all stages of production to ensure quality products at the most economic levels. 
The PROMETHEE technique requires two types of information: alternatives and criteria. In order to follow this technique, an investigation has been operated to get quantitative data. A questionnaire is produced using 5 alternatives among the various alternatives namely entry modes: exporting, franchising, licensing, FDI and joint venture. Those entry modes are selected based on the literature review and the type of entry modes which appears convenient for this study.

Then we used 15 influential factors called criteria. The selections are made based on the political situation, cultural difference and economic competitiveness and there are presented in the table below (Table 2).

Table 2. The matrix of 5 entry modes with 15 influencing factors.

\begin{tabular}{|c|c|c|c|c|c|}
\hline \multirow{2}{*}{$\begin{array}{l}\text { FACTOR CRITERIA } \\
\text { SCALE }\end{array}$} & \multicolumn{5}{|c|}{ MODES } \\
\hline & EXPORTING & FRANCHISING & LICENSING & $\begin{array}{l}\text { FOREIGN DIRECT } \\
\text { INVESTMENT }\end{array}$ & $\begin{array}{c}\text { JOINT } \\
\text { VENTURE }\end{array}$ \\
\hline \multirow{5}{*}{$\begin{array}{l}\text { MARKET } \\
\text { POTENTIAL } \\
(1-5)\end{array}$} & 2 & 3 & 3 & 4 & 4 \\
\hline & 1 & 3 & 1 & 3 & 4 \\
\hline & 2 & 4 & 2 & 3 & 5 \\
\hline & 3 & 4 & 1 & 5 & 4 \\
\hline & 1 & 5 & 1 & 3 & 4 \\
\hline \multirow{7}{*}{$\begin{array}{c}\text { PRODUCTION } \\
\text { FACTORS } \\
(1-5)\end{array}$} & 1 & 4 & 4 & 4 & 5 \\
\hline & 1 & 3 & 2 & 4 & 1 \\
\hline & 1 & 3 & 1 & 3 & 1 \\
\hline & 1 & 3 & 1 & 3 & 2 \\
\hline & 1 & 3 & 1 & 3 & 1 \\
\hline & 1 & 3 & 1 & 4 & 1 \\
\hline & 1 & 4 & 1 & 4 & 1 \\
\hline \multirow{6}{*}{$\begin{array}{c}\text { GEOGRAPHICAL } \\
\text { DISTANCE } \\
(1-5)\end{array}$} & 2 & 4 & 1 & 2 & 1 \\
\hline & 2 & 4 & 3 & 1 & 4 \\
\hline & 2 & 3 & 4 & 1 & 3 \\
\hline & 1 & 4 & 2 & 1 & 2 \\
\hline & 1 & 4 & 2 & 1 & 3 \\
\hline & 1 & 3 & 2 & 1 & 2 \\
\hline \multirow{6}{*}{$\begin{array}{l}\text { CULTURAL } \\
\text { DISTANCE } \\
(1-5)\end{array}$} & 3 & 4 & 3 & 1 & 2 \\
\hline & 1 & 4 & 5 & 1 & 1 \\
\hline & 1 & 3 & 5 & 1 & 1 \\
\hline & 1 & 4 & 4 & 1 & 1 \\
\hline & 2 & 4 & 4 & 1 & 1 \\
\hline & 2 & 3 & 5 & 1 & 2 \\
\hline \multirow{6}{*}{$\begin{array}{l}\text { MARKET BARRIERS } \\
(1-5)\end{array}$} & 4 & 1 & 3 & 2 & 4 \\
\hline & 5 & 1 & 3 & 2 & 5 \\
\hline & 3 & 2 & 4 & 2 & 5 \\
\hline & 4 & 2 & 3 & 3 & 4 \\
\hline & 5 & 2 & 4 & 3 & 3 \\
\hline & 6 & 2 & 2 & 1 & 4 \\
\hline \multirow{6}{*}{$\begin{array}{l}\text { GOVERNMENT } \\
\text { POLICIES AND } \\
\text { REGULATIONS } \\
\quad(1-5)\end{array}$} & 3 & 2 & 5 & 1 & 3 \\
\hline & 4 & 2 & 4 & 1 & 3 \\
\hline & 2 & 1 & 4 & 1 & 4 \\
\hline & 2 & 1 & 3 & 1 & 3 \\
\hline & 3 & 1 & 4 & 2 & 2 \\
\hline & 3 & 2 & 3 & 1 & 4 \\
\hline
\end{tabular}




\begin{tabular}{|c|c|c|c|c|c|}
\hline \multicolumn{6}{|l|}{ Continued } \\
\hline \multirow{6}{*}{$\begin{array}{l}\text { DEMAND } \\
\text { UNCERTAINTY } \\
(1-5)\end{array}$} & 3 & 1 & 2 & 2 & 3 \\
\hline & 3 & 1 & 1 & 2 & 4 \\
\hline & 2 & 2 & 4 & 3 & 1 \\
\hline & 1 & 2 & 2 & 2 & 2 \\
\hline & 2 & 1 & 2 & 2 & 2 \\
\hline & 3 & 2 & 3 & 2 & 3 \\
\hline \multirow{5}{*}{$\begin{array}{l}\text { ENVIRONMENT } \\
\text { FACTORS } \\
(1-5)\end{array}$} & 1 & 3 & 3 & 3 & 4 \\
\hline & 1 & 4 & 4 & 2 & 4 \\
\hline & 1 & 3 & 3 & 3 & 4 \\
\hline & 1 & 3 & 3 & 3 & 4 \\
\hline & 1 & 4 & 4 & 2 & 3 \\
\hline \multirow{7}{*}{$\begin{array}{l}\text { SIZE OF THE } \\
\text { COMPANY } \\
(1-5)\end{array}$} & 1 & 2 & 4 & 4 & 3 \\
\hline & 2 & 3 & 3 & 3 & 4 \\
\hline & 2 & 3 & 3 & 3 & 2 \\
\hline & 1 & 2 & 2 & 2 & 4 \\
\hline & 1 & 3 & 2 & 2 & 3 \\
\hline & 1 & 2 & 2 & 2 & 3 \\
\hline & 1 & 3 & 2 & 2 & 3 \\
\hline \multirow{5}{*}{$\begin{array}{c}\text { INTERNATIONAL } \\
\text { EXPERIENCE } \\
(1-5)\end{array}$} & 1 & 4 & 2 & 2 & 1 \\
\hline & 1 & 3 & 1 & 1 & 1 \\
\hline & 1 & 4 & 3 & 1 & 1 \\
\hline & 1 & 4 & 2 & 1 & 2 \\
\hline & 2 & 4 & 2 & 2 & 1 \\
\hline \multirow{7}{*}{$\begin{array}{l}\text { COMPETITIVE } \\
\text { STRUCTURE } \\
(1-5)\end{array}$} & 1 & 4 & 2 & 2 & 1 \\
\hline & 3 & 2 & 2 & 4 & 3 \\
\hline & 4 & 2 & 2 & 4 & 2 \\
\hline & 4 & 3 & 2 & 5 & 2 \\
\hline & 3 & 1 & 2 & 4 & 2 \\
\hline & 3 & 2 & 1 & 5 & 1 \\
\hline & 4 & 1 & 1 & 5 & 1 \\
\hline \multirow{6}{*}{$\begin{array}{l}\text { POLITICAL RISK } \\
(1-5)\end{array}$} & 5 & 4 & 5 & 5 & 5 \\
\hline & 4 & 4 & 5 & 5 & 4 \\
\hline & 4 & 3 & 4 & 4 & 3 \\
\hline & 3 & 4 & 4 & 5 & 3 \\
\hline & 3 & 4 & 5 & 4 & 4 \\
\hline & 3 & 4 & 4 & 5 & 3 \\
\hline \multirow{6}{*}{$\begin{array}{c}\text { MANAGEMENT RISK } \\
\text { ATTITUDE } \\
(1-5)\end{array}$} & 3 & 2 & 3 & 4 & 2 \\
\hline & 3 & 2 & 1 & 3 & 3 \\
\hline & 3 & 3 & 2 & 4 & 4 \\
\hline & 4 & 2 & 2 & 4 & 4 \\
\hline & 3 & 2 & 3 & 4 & 2 \\
\hline & 3 & 2 & 3 & 4 & 3 \\
\hline \multirow{5}{*}{$\begin{array}{l}\text { HOME COUNTRY } \\
\text { FACTORS } \\
(1-5)\end{array}$} & 3 & 1 & 1 & 1 & 2 \\
\hline & 2 & 1 & 1 & 2 & 2 \\
\hline & 3 & 1 & 1 & 1 & 2 \\
\hline & 2 & 1 & 1 & 2 & 3 \\
\hline & 1 & 2 & 2 & 1 & 3 \\
\hline \multirow{7}{*}{$\begin{array}{l}\text { QUALITY, } \\
\text { QUANTITY AND } \\
\text { COST } \\
(1-5)\end{array}$} & 2 & 1 & 1 & 1 & 2 \\
\hline & 4 & 3 & 2 & 3 & 3 \\
\hline & 3 & 3 & 3 & 4 & 3 \\
\hline & 4 & 3 & 3 & 4 & 2 \\
\hline & 3 & 4 & 3 & 4 & 2 \\
\hline & 2 & 3 & 2 & 2 & 3 \\
\hline & 4 & 3 & 3 & 3 & 2 \\
\hline
\end{tabular}


After the questionnaire is made, six independents experts fill the form and we assume that there is no communication between the experts and they ignore the existence of each other. Unfortunately fewer experts in the specialized field were not available. So this paper did focus on the availability of the data about the six independent experts.

The scores are based on their personal experience, knowledge about international business and the expansion of a company abroad. The experts choose the score between 1 to 5 based on the relationship between each factor and the entry mode. When the score is close to 5 , it means there is a strong effect that the influencing factor has on a specific entry mode. Each score for each entry modes is influenced by the factor criteria. So the difference is about the impact factor of entry modes on the factor criteria scale.

\section{Results and Discussion}

\subsection{PROMETHEE Rankings}

The results below are obtained using the PROMETHEE II method which gives the net outranking flow.

In Table 3, PROMETHEE Flow Table we can see Phi, Phi+, Phi- score. Entry modes are ordered by PROMETHEE II complete ranking. The positive flow expresses how much an alternative is dominating the other ones, and the negative flow how much it is dominated by the other ones. Joint venture ranks first among the five other entry modes.

\subsection{PROMETHEE Network}

In PROMETHEE Network, Joint venture still dominates the others entry modes. Figure 1 shows the PROMETHEE Network which presents PROMETHEE I partial ranking. Entry modes are nodes and preferences are indicated by arrows. Joint venture is significantly preferred to other entry modes. Exporting and foreign direct investment (FDI) are incomparable and very close to each other. Licensing alternative ranked the second and franchising alternative ranked the third.

\section{VISULA Analysis}

A look on the PROMETHEE II complete ranking and PROMETHEE diamond (see Figure 2, Figure 3) already helps us drawing some interesting conclusions.

In this section, the vertical axis (Figure 2, Figure 3) represents the weighting index between-1 and 1 (minus one and one). It indicates the index rate of each entry mode where the direction of the best actions are located from up to down according to the weights given to the criteria. In our example, it is oriented upwards, in the direction of joint venture and licensing. The results presented by rankings the alternatives from Table 3 to Figure 1, Figure 2 and Figure 3 show the same result therefore we can conclude that the result is accurate. The best entry mode, taking into account its appropriateness as the institutional agreement allowing the considered company to enter in this market, is joint venture or licensing. Franchising does not seem appropriate entry mode for organizing business activities by the company in the target market. Finally, the worst modes for the company to expand in this market are foreign direct investment and exporting.

\section{Conclusions}

According to previous studies, entry mode decisions have always been one of the most critical decisions, in international expansion because the decision of how to penetrate a foreign market can have an important effect on the

\begin{tabular}{ccccc}
\hline \multicolumn{2}{l}{ Table 3. Preference flows. } & & \\
\hline rank & action & Phi & Phi+ & Phi- \\
\hline $\mathbf{1}$ & joint-venture & 0.1607 & 0.5536 & 0.3929 \\
$\mathbf{2}$ & licensing & 0.0714 & 0.5000 & 0.4286 \\
$\mathbf{3}$ & franchising & -0.0179 & 0.4821 & 0.5000 \\
$\mathbf{4}$ & exporting & -0.1071 & 0.4107 & 0.5179 \\
$\mathbf{5}$ & FDI & -0.1071 & 0.4286 & 0.5357 \\
\hline
\end{tabular}




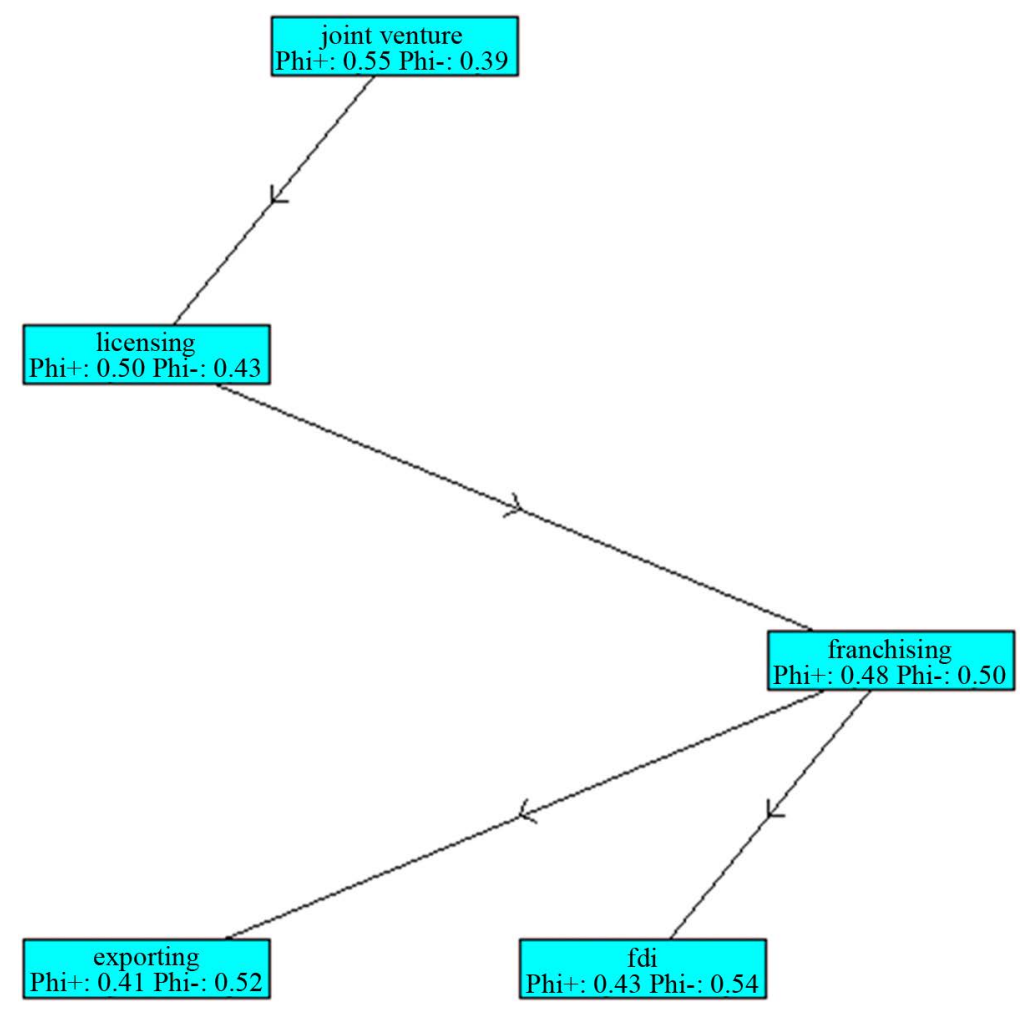

Figure 1. PROMETHEE network.

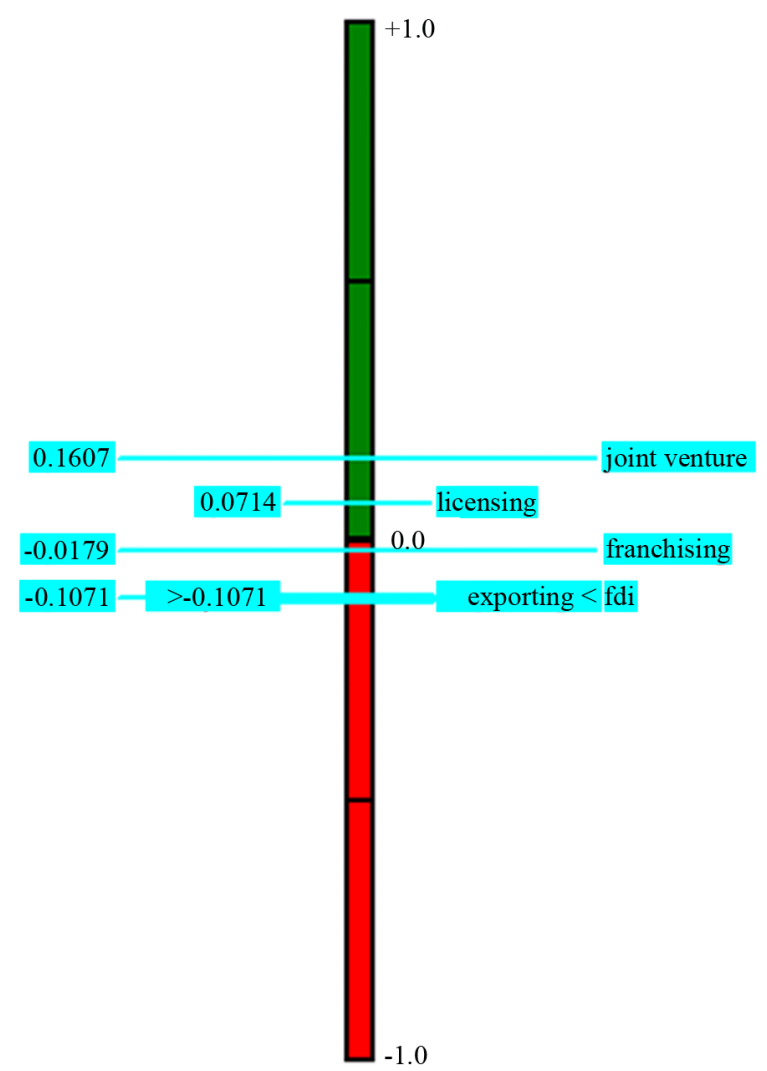

Figure 2. PROMETHEE II complete ranking. 


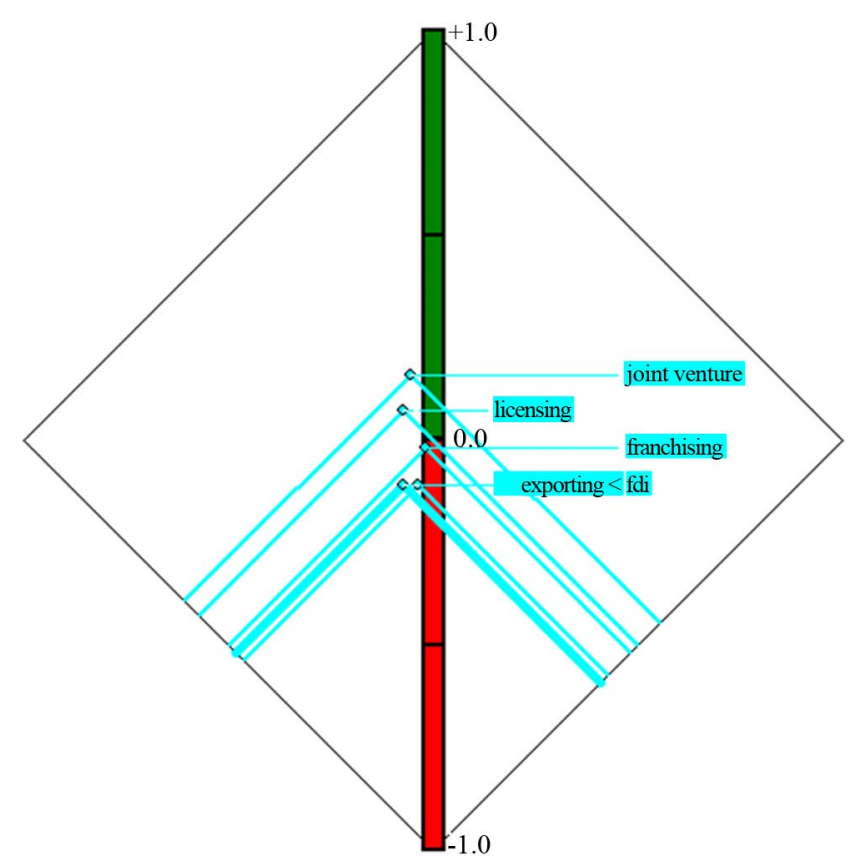

Figure 3. PROMETHEE diamond.

results. It is therefore important to select the most appropriate entry mode for a given company application which will minimize some mistakes and allow it to achieve growth internationally. The present study explores the use of PROMETHEE-GAIA method in solving an entry modes selection problem and the results obtained can be valuable to the decision maker in framing the entry mode selection strategies. This method allows for a model numeric processing of the problem and for presenting numerical and graphical results of ranking alternatives.

It is also observed that this MCDM approach is a viable tool in solving the entry mode selection decision problems. It allows the decision maker to rank the candidate alternatives more efficiently and easily. Actually, applying this approach can develop the evaluation process and improve decision-making since the assumptions on which it is based are in line with reality. Based on ranking, a definitive choice of the best solution at all the criteria is the choice of joint venture and which can be clearly seen above. Most of the studies recommend joint venture as entry mode in foreign market. The result from our study is relevant with others studies. The approach discussed can be applied or guide-lines to any company searching for a way to enter the target market and launch its business activities.

\section{References}

[1] Papadopoulos, N. (1988) Inventory Taxonomy and Assessment of Methods for International Market Selection. International Marketing Review, 5, 38-51. http://dx.doi.org/10.1108/eb008357

[2] O’Farrell, P.N. and Wood, P.A. (1994) International Market Selection by Business Service Firms: Key Conceptual and Methodological Issues. International Business Review, 3, 243-261. http://dx.doi.org/10.1016/0969-5931(94)90004-3

[3] Pan, Y. and Tse, D.K. (2000) The Hierachical Model of Market Entry Modes. Journal of International Business Studies, 31, 535-554. http://dx.doi.org/10.1057/palgrave.jibs.8490921

[4] Deresky, H. (2000) International Management. 3rd Edition, Prentice Hall, New Jersey.

[5] Ekeledo, I. and Sivakumar, K. (2004) International Market Entry Mode Strategies of Manufacturing Firms and Service Firms: A Resource-Based Perspective. International Marketing Review, 21, 68. http://dx.doi.org/10.1108/02651330410522943

[6] Root, F.R. (1994) Entry Strategies for International Markets. Jossey-Bass, San Francisco.

[7] Chen, L.Y. and Mujtaba, B. (2007) The Choice of Entry Mode Strategies and Decisions for International Market Expansion. Journal of American of Business, 10, 322.

[8] Koch, A.J. (2001) Selecting Overseas Markets and Entry Modes: Two Decision Process or One? Marketing Intelli- 
gence \& Planning, 19, 351-361. http://dx.doi.org/10.1108/EUM0000000005652

[9] Brassington, F. and Pettitt, S. (2000) Principles of Marketing. Second Edition, Financial Times Management, Harlow, London.

[10] Hollenssen, H. (2001) Determinant of International Activities: Are SME’s Different? Small Business Economics, 24, 431-450. http://dx.doi.org/10.1007/s11187-005-6455-x

[11] Hollensen, S. (1998) Global Marketing-Market-Respective Approach. Prentice Hall, Hertfordshire.

[12] Hill, C.W.L. (2007) International Business-Competing in the Global Market. McGraw-Hill, Boston.

[13] Armstrong, G. and Kolter, P. (2005) Principles of Marketing. 7th Edition, Prentice Hall, Upper Saddle River, 581 p.

[14] Buckley, P.J. and Casson, M.C. (1998) Analyzing Foreign Market Entry Strategies: Extending the Internationalization Approach. Journal of International Business Studies, 29, 539-561. http://dx.doi.org/10.1057/palgrave.jibs.8490006

[15] Prescott, D. and Swartz, S. (2010) Joint Ventures in International Arena. 2nd Edition, ABA Publishing, American Bar Association, Chicago.

[16] Bradley, F. (2005) International Marketing Strategy. 5th Edition, Prentice Hall, New York.

[17] Sitek, E. (2000) Inwestycjebezposrednieprzedsiebiorstwanarynkuzagranicznym. Wydawnictwo Wydzialu Zarzadzania Politechniki Czestochowskiej, Czestochowa.

[18] Rymarczyk, J. (2004) Internacjonalizacja i globalizacjaprzedsiebiorstwa. Polskie Wydawnictwo Ekonomiczne, Warszawa.

[19] Duliniec, E. (2009) Marketing Miedzynarodowy. Polskie Wydawnictwo Ekonomiczne, Warszawa.

[20] Brans, J.P. and Vincke, P. (1985) A Preference Ranking Organisation Method: (The PROMETHEE Method for Multiple Criteria. Decision-Making). Management Science, 31, 647-656. http://dx.doi.org/10.1287/mnsc.31.6.647 